\title{
Cationic Telomerization of Olefin with Isocyanide as Telogen
}

\author{
Takeo SAegusa, Naotake TAKA-ISHI, and Yoshihiko Ito \\ Department of Synthetic Chemistry, Faculty of Engineering, \\ Kyoto University, Kyoto, Japan.
}

(Received May 2, 1970)

\begin{abstract}
Telomerization of vinyl ether as taxogen with $t$-butyl isocyanide as the telogen was carried out at room temperature using $\mathrm{BF}_{3} \mathrm{OEt}_{2}$ catalyst. Telomers were obtained along with the isomer and isomerized dimer of $t$-butyl isocyanide. On the basis of a previous study on the cationic isomerization and oligomerization of tertiary alkyl isocyanide, the formations of the telomers of the present reaction were schematized. $\alpha$-Methylstyrene and 4,5-dihydropyran were also found to react with $t$-butyl isocyanide to produce the corresponding $1: 1$ adducts.

KEY WORDS Telomerization / Vinyl Ether / $t$-Butyl Isocyanide / Boronfluoride / Telogen / Cationic Isomerization / $\beta$-Scission / Imidoyl Cation / $\alpha$-Methylstyrene / 4,5-Dihydropyran /
\end{abstract}

Isocyanide (1) is a nucleophile due to the lone-pair electrons of the terminal carbon atom. Primary and secondary alkyl isocyanides are polymerized by Lewis acid to produce an insoluble and infusible polymer ${ }^{1}$. Tertiary alkyl isocyanide, on the other hand, is isomerized and oligomerized by Lewis acid catalyst. ${ }^{2}$ The courses of cationic isomerization and oligomerization of tertiary alkyl isocyanide are wellexplained by assuming imidoyl cations (3, 5 and 6$)$ as the key intermediates.

The $\beta$-scission of imidoyl cation 3 produces the isomer cyanide 4 and the cation of the isocyanide's alkyl 2 . The reaction of 1 with 2 producing 4 and 2 corresponds to the isomerization. In the $\beta$-scission of the second imidoyl cation $\mathbf{5}$, the dimer is produced and the cation of the isocyanide's alkyl is regenerated. Thus the oligomerization of tertiary alkyl isocyanide is formulated as being a consecutive series of three elemental reactions, the addition of a tertiary alkyl cation to isocyanide (initiation), the addition of an imidoyl cation to isocyanide (propagation) and the $\beta$-scission of the propagating imidoyl cation (chain transfer).

This paper reports on the cationic telomerization of olefins with tertiary alkyl isocyanide as the telogen. In this reaction, tertiary alkyl isocyanide is a powerful chain transfer agent.

\section{RESULTS AND DISCUSSION}

When a mixture of $t$-butyl isocyanide and isobutyl vinyl ether was treated with $\mathrm{BF}_{3} \mathrm{OEt}_{2}$ in methylene dichloride at room temperature, the following six products $(\mathbf{7} \rightarrow \mathbf{1 2 a})$ were isolated from the reaction mixture (Table I).

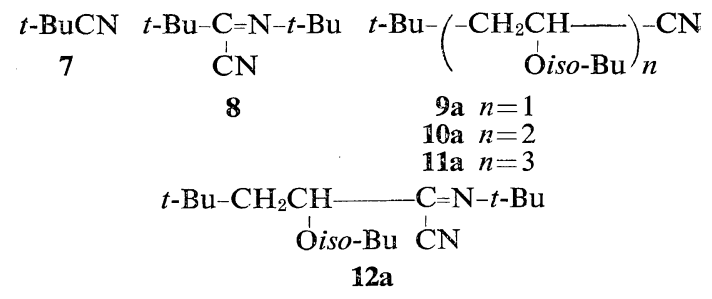

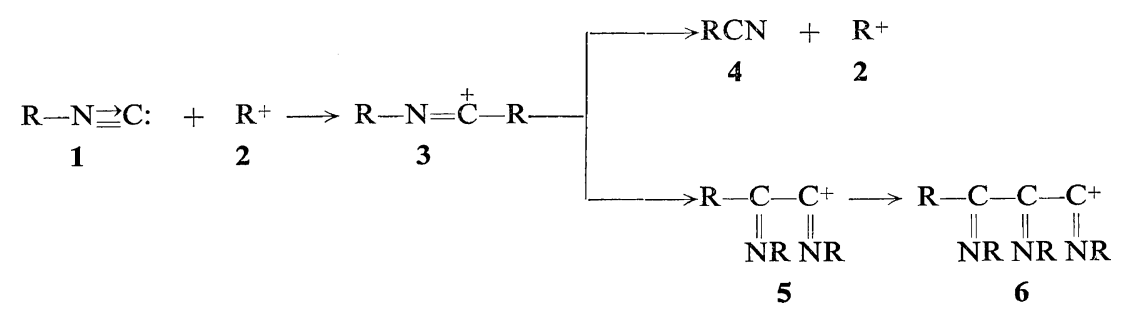


Among these products, $\mathbf{7}$ and $\mathbf{8}$ are the isomer and isomerized dimer, both of which are produced from $t$-butyl isocyanide with $\mathrm{BF}_{3} \mathrm{OEt}_{2}$ in the absence of vinyl ether. The products of 9a, 10a and 11a are the $1: 1,1: 2$ and $1: 3$ telomers, respectively, which consist of the vinyl ether taxogen and the $t$-butyl isocyanide telogen. It is of interest to note that the direction of bonding of the $\mathrm{CN}$ group in the telomers is opposite to that of the isocyanide telogen. The telomers having the same back-bone structure were formed also in the free-radical telomerization of olefins with $t$-butyl isocyanide. ${ }^{3}$ The IR spectra of these telomers are shown in Figure 1. The product 12a may be regarded as a 2:1 telomer; i.e., it consists of one mole of vinyl ether and two moles of $t$-butyl isocyanide.

With reference to the mechanistic scheme of the cationic isomerization and oligomerization of tertiary alkyl isocyanide, ${ }^{2}$ the formations of

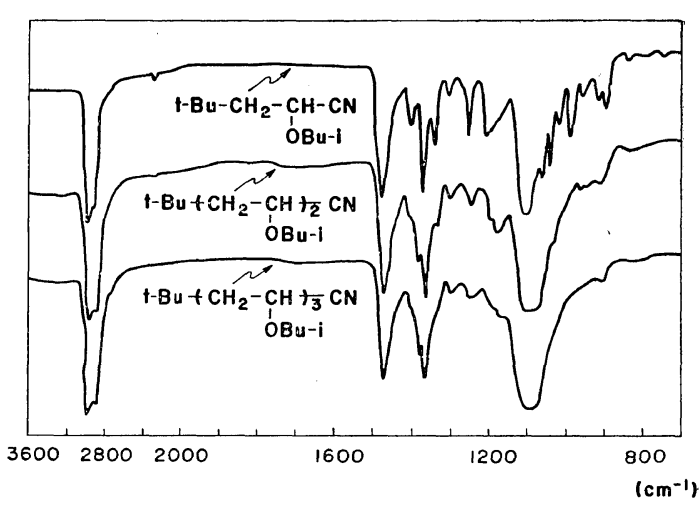

Figure 1. The IR spectra of telomers.

the six products of the present reaction are schematized in Diagram I. The elementary reactions in this diagram are the additions of a cation to one of two nucleophiles, isocyanide and vinyl ether, and the $\beta$-scissions of imidoyl

\section{Diagram I}

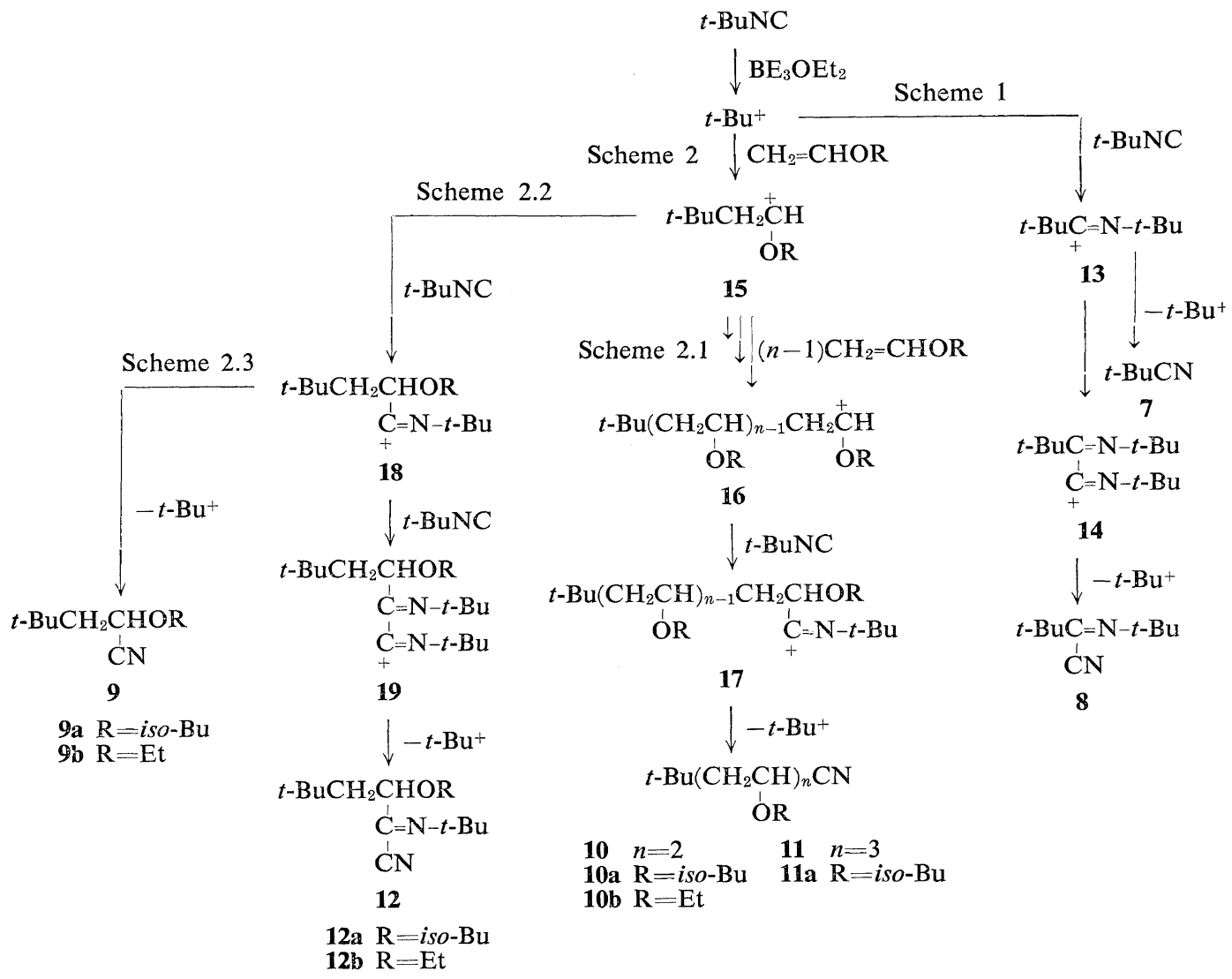


Table I. Cationic telomerization of isobutyl vinyl ether with $t$-butyl isocyanide as telogen using $\mathrm{BF}_{3} \mathrm{OEt}_{2}$ catalysta

\begin{tabular}{|c|c|}
\hline Products & Yield, $\%$ \\
\hline$t-\mathrm{BuCN}$ & 47 \\
\hline $\begin{array}{c}t-\mathrm{Bu}-\mathrm{C}=\mathrm{N}-t-\mathrm{Bu} \\
\stackrel{\mathrm{I}}{\mathrm{CN}}\end{array}$ & 31 \\
\hline $\begin{array}{l}t-\mathrm{Bu}-\mathrm{CH}_{2} \mathrm{CHCN} \\
\text { Oiso- } \mathrm{Bu}\end{array}$ & 3 \\
\hline $\begin{array}{c}t-\mathrm{Bu}-\left(\mathrm{CH}_{2} \mathrm{CH}\right)_{2}-\mathrm{CN} \\
\text { Oiso-Bu }\end{array}$ & 4.5 \\
\hline $\begin{array}{c}t-\mathrm{Bu}-\left(\mathrm{CH}_{2} \mathrm{CH}\right)_{3}-\mathrm{CN} \\
\text { Oiso-Bu }\end{array}$ & 4.5 \\
\hline $\begin{array}{c}\mathrm{CN} \\
t-\mathrm{Bu}-\mathrm{CH}_{2} \mathrm{CH}-\stackrel{\mathrm{C}}{\mathrm{C}}=\mathrm{N}-t-\mathrm{Bu} \quad(\mathbf{1 2 \mathrm { a }}) \\
\text { Oiso-Bu }\end{array}$ & 5 \\
\hline
\end{tabular}

a Telomerization conditions: $t$-BuNC, $112 \mathrm{mmol}$; $\mathrm{CH}_{2}=\mathrm{CHO}$ iso- $\mathrm{Bu}, \quad 76 \mathrm{mmol}, \quad \mathrm{BF}_{3} \mathrm{OEt}, \quad 7 \mathrm{mmol}$; $\mathrm{CH}_{2} \mathrm{Cl}_{2}, 50 \mathrm{ml}$; One day's duration, at room temp.

cations regenerating the $t$-butyl cation. Every scheme is a combination of these elementary reactions, which start with the addition of a $t$-butyl cation to a nucleophile and end with the regeneration of a $t$-butyl cation. As to the initial generation of the $t$-butyl cation complex, two possible processes may be assumed, i.e., the direct interaction of $t$-butyl isocyanide with $\mathrm{BF}_{3} \mathrm{OEt}_{2}$ (eq 1) and the participation of a protonic acid due to a small amount of water impurity (eq 2).

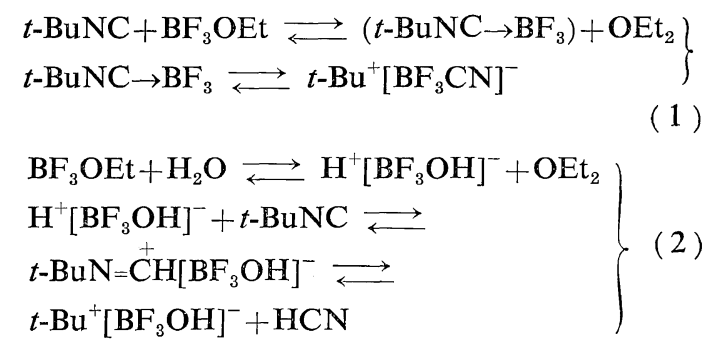

In scheme 1 , the addition of a $t$-butyl cation to $t$-butyl isocyanide produces an imidoyl cation $\mathbf{1 4}$ whose decomposition gives 7 . The addition of 13 to the second molecule of $t$-butyl isocyanide yields another imidoyl cation 14 which decomposes into $\mathbf{8}$ and $t$-butyl cation. Scheme 2 is the course of telomerization, which is initiated by the attack of the $t$-butyl cation on vinyl ether affording a cation 15. Successive additions of 15 to one and two molecules of vinyl ether followed by the addition of $\mathbf{1 6}(n=2$ and 3$)$ to $t$-butyl isocyanide give rise to two telomers of $\mathbf{1 0}$ and 11. The formation of 9 is explained by the sequence of $\mathbf{1 5}$ to $\mathbf{1 8}$ to $\mathbf{9}$. The sequence of $\mathbf{1 5}$ to 18 to 19 ends with the production of 12.

Scheme 1 and 2 bifurcate according to the additions of $t$-butyl cation to isocyanide and vinyl ether, respectively. The combined yield of 7 and 8 is higher than that of the products from 9 to 12. This fact suggests that $t$-butyl isocyanide is more nucleophilic than vinyl ether.

Styrene is also a cationically polymerizable monomer, which, however, does not enter into the reaction with isocyanide. Only 7 and 8 were produced in the treatment of a mixture of $t$-butyl isocyanide and styrene with a catalyst of $\mathrm{BF}_{3} \mathrm{OEt}_{2}$. Also in the case of $p$-methoxystyrene, no telomer was formed. However, $\alpha$-methylstyrene was reacted with $t$-butyl isocyanide to produce an 1:1 adduct of 20. The formation of 20 is rationalized by scheme 2.2 and 2.3 in Diagram I.

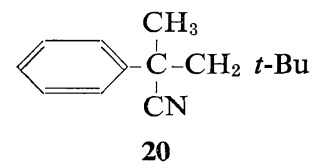

\section{EXPERIMENTAL}

\section{Reagents}

$t$-Butyl isocyanide was prepared according to Ugi's procedure. ${ }^{4}$ Commercial methylene chloride, isobutyl vinyl ether, ethyl vinyl ether, 4,5dihydropyran and $\alpha$-methyl styrene were purified by the usual methods. Commercial borontrifluoride etherate $\left(\mathrm{BF}_{3} \mathrm{OEt}_{2}\right)$ was used without purification.

\section{Telomerization of Isobutyl Vinyl Ether with t-} Butyl Isocyanide as Telogen

Under nitrogen atmosphere at room temperature, $7 \mathrm{mmol}$ of $\mathrm{BF}_{3} \mathrm{OEt}_{2}$ in $7 \mathrm{ml}$ of methylene choride was added dropwise to a mixture of $10 \mathrm{~m} l(112 \mathrm{mmol})$ of $t$-butyl isocyanide and $10 \mathrm{~m} l$ $(76 \mathrm{mmol})$ of isobutyl vinyl ether in $50 \mathrm{~m} l$ of methylene chloride. An exothermic reaction 
began immediately, and the reaction mixture turned red-brown. The mixture was allowed to stand at room temperature for one day, and then was quenched with aqueous sodium bicarbonate. The methylene chloride layer was subjected to distillation. From the fractions of distillation, four products, 9a, 10a, 11a and 12a, were isolated by preparative GLPC. The amounts of $\mathbf{7}$ and $\mathbf{8}$ were determined by GLPC analysis using the corresponding authentic samples.

From the first fraction (bp $\left.87^{\circ} \mathrm{C}(10 \mathrm{~mm})\right)$, 2isobutoxy-4,4-dimethylvaleronitrile (9a) was obtained by means of preparative GLPC in a yield of $3 \%$. NMR $\left(\mathrm{CDCl}_{3}\right): \tau 5.90(1 \mathrm{H}$, triplet, $-\mathrm{CH}(\mathrm{CN})-\mathrm{O}-), 6.65\left(2 \mathrm{H}\right.$, multiplet, $\left.-\mathrm{OCH}_{2}-\mathrm{CH}\right)$, 7.8-8.5 (3H, complex multiplet, $-\mathrm{OCH}_{2}-$ $\mathrm{CH}\left(\mathrm{CH}_{3}\right)_{2}, t$ - $\left.\mathrm{Bu}-\mathrm{CH}_{2}^{-}\right), 9.00(9 \mathrm{H}$, singlet, $t$ - $\mathrm{Bu}-)$, and $9.05 \mathrm{ppm}\left(6 \overline{\mathrm{H}}\right.$, doublet, $\left.-\mathrm{CH}_{2} \mathrm{CH}\left(\mathrm{CH}_{3}\right)_{2}\right)$.

Anal. Calcd for $\mathrm{C}_{11} \mathrm{H}_{21} \mathrm{NO}: \mathrm{C}, 72.08, \mathrm{H}$, 11.55; N, 7.64. Found: C, 72.14; H, 11.36; N, 7.55 .

From the second fraction (bp $100-120^{\circ} \mathrm{C}(3.5$ $\mathrm{mm})$ ), the $1: 2$ telomers (10a) and (12a) were obtained by means of preparative GLPC, in yields of $4.5 \%$ and $5 \%$, respectively. 2,4-Diisobutoxy-6,6-dimethylheptanenitrile (10a). NMR $\left(\mathrm{CDCl}_{3}\right): \tau 5.75(1 \mathrm{H}$, triplet, $-\mathrm{CH}(\mathrm{CN})-\mathrm{O}-), 6.2-$ $7.1\left(5 \mathrm{H}\right.$, complex multiplet, $-\mathrm{CH}_{2} \mathrm{CH}-\mathrm{O}-\mathrm{CH}_{2}-$ and $\left.-\mathrm{CH}(\mathrm{CN})-\mathrm{O}-\mathrm{CH}_{2}-\right), 7.8-8.8(\overline{6 \mathrm{H}}$, complex multiplet, $t$-Bu- $\mathrm{CH}_{2}-, 2 \times-\mathrm{OCH}_{2}-\mathrm{CH}\left(\mathrm{CH}_{3}\right)_{2}$ and $\mathrm{CH}-\mathrm{CH}_{2}-\mathrm{CH}(\mathrm{CN})-\mathrm{O}-$, and $8.9-9.2 \mathrm{ppm}(21 \mathrm{H}$, complex multiplet, $t$ - $\mathrm{Bu}-\mathrm{CH}_{2-}$, and $2 \times-\mathrm{OCH}_{2-}$ $\left.\mathrm{CH}\left(\mathrm{CH}_{3}\right)_{2}\right)$.

Anal. Calcd for $\mathrm{C}_{17} \mathrm{H}_{33} \mathrm{NO}_{2}: \mathrm{C}, 72.04 ; \mathrm{H}$, 11.74; N, 4.94. Found: C, 72.17; H, 11.97; N, 4.81. 2-t-Butylimino-3-isobutoxy-5, 5-dimethylcapronitrile (12a). IR (neat): $2200\left(\nu_{\mathrm{C} \equiv \mathrm{N}}\right)$ and $1625 \mathrm{~cm}^{-1}\left(\nu_{\mathrm{C}=\mathrm{N}}\right)$. NMR $\left(\mathrm{CDCl}_{3}\right): \tau 6.08(1 \mathrm{H}$, multiplet, $-\mathrm{CH}(\mathrm{CN}) \mathrm{O}), \quad 6.85 \quad(2 \mathrm{H}$, doublet, -O- $\left.\mathrm{CH}_{2}-\right)$, 8.0-8.8 (3H, complex multiplet, $-\mathrm{OCH}_{2}-\mathrm{CH}\left(\mathrm{CH}_{3}\right)_{2}$ and $\left.t-\mathrm{Bu}-\mathrm{CH}_{2}-\right), 8.58(9 \mathrm{H}$, singlet, $t$ - $\mathrm{Bu}-\mathrm{N}=\mathrm{C}-), 9.03(9 \mathrm{H}$, singlet, $t$ - $\mathrm{Bu}-$ $\mathrm{CH}_{2^{-}}$), and $9.10 \mathrm{ppm}\left(6 \mathrm{H}\right.$, doublet, $\left.\left(\mathrm{CH}_{3}\right)_{2} \overline{\mathrm{CH}-}\right)$.

Anal. Calcd for $\mathrm{C}_{16} \mathrm{H}_{30} \mathrm{~N}_{2} \mathrm{O}: \mathrm{C}, 72.13 ; \mathrm{H}$, $11.35 ; \mathrm{N}, 10.52$. Found: C, 71.55; H, 11.60; $\mathrm{N}, 9.94$.

From the third fraction (bp $140-164^{\circ} \mathrm{C}(3.5$ $\mathrm{mm})$ ), the $1: 3$ telomer, 2,4,6-triisobutoxy-8,8dimethylnonanenitrile (11a), was isolated by means of preparative GLPC in a yield of $4.5 \%$. NMR $\left(\mathrm{CDCl}_{3}\right)$ : similar to $1: 2$ adduct $(\mathbf{1 0 a})$.

Anal. Calcd for $\mathrm{C}_{23} \mathrm{H}_{45} \mathrm{NO}_{3}: \mathrm{C}, 72.01 ; \mathrm{H}$, $11.82 ; \mathrm{N}, 3.65$. Found: C, $72.24 ; \mathrm{H}, 12.03, \mathrm{~N}$, 3.46 .

\section{Telomerization of Ethyl Vinyl Ether with t-Butyl} Isocyanide as Telogen

The reaction procedure was almost the same as that described above. The distillate was analyzed by GLPC and the four telomerization products were isolated by preparative GLPC. 2-Ethoxy-4,4-dimethylvaleronitrile (9b, $1: 1$ telomer) was obtained from the distillate boiling $90-92^{\circ} \mathrm{C}(24 \mathrm{~mm})$ in a yield of $4 \%$. IR (neat): $2230 \mathrm{~cm}^{-1}\left(\nu_{\mathrm{C} \equiv N}\right)$. NMR $\left(\mathrm{CDCl}_{3}\right): \tau 5.83(1 \mathrm{H}$, triplet, $-\mathrm{CH}(\mathrm{CN}) \mathrm{O}-), \quad 6.32 \quad(2 \mathrm{H}, \quad$ multiplet, $\left.{ }_{-} \mathrm{OCH}_{2}-\right), 8.17\left(2 \mathrm{H}\right.$, doublet, $\left.t-\mathrm{Bu}_{-} \mathrm{CH}_{2^{-}}\right), 8.73$ $\left(3 \mathrm{H}\right.$, triplet, $\left.\mathrm{CH}_{3} \mathrm{CH}_{2} \mathrm{O}\right)$, and $8.98 \mathrm{ppm}(9 \mathrm{H}$, singlet, $t$-Bu-).

Anal. Calcd for $\mathrm{C}_{9} \mathrm{H}_{17} \mathrm{NO}$ : $\mathrm{C}, 69.63 ; \mathrm{H}, 11.04$; $\mathrm{N}, 9.02$. Found: C, 69.76; H, 11.23; N, 8.86. 2-t-Butylimino-3-ethoxy-5, 5-dimethylcapronitrile $(\mathbf{1 2 b}, 2: 1$ telomer) was obtained from the distillate boiling at $70-80^{\circ} \mathrm{C}(4 \mathrm{~mm})$ in a yield of $3 \%$ IR (neat): $2200\left(\nu_{\mathrm{C} \equiv \mathrm{N}}\right)$ and $1625 \mathrm{~cm}^{-1}$ $\left(\nu_{\mathrm{C}=\mathrm{N}}\right)$. NMR $\left(\mathrm{CDCl}_{3}\right): \tau 5.98(1 \mathrm{H}$, multiplet, $\left.-\mathrm{CHOCH}_{2}\right), 6.50\left(2 \mathrm{H}\right.$, multiplet, $\left.-\mathrm{OCH}_{2} \mathrm{CH}_{3}\right)$, $8.35\left(2 \mathrm{H}\right.$, multiplet, $t$ - $\left.\mathrm{BuCH}_{2}{ }^{-}\right), 8.55(9 \overline{\mathrm{H}}$, singlet, $t-\mathrm{BuN}=\mathrm{C}-), 8.75\left(3 \mathrm{H}\right.$, triplet, $\left.\mathrm{CH}_{3} \mathrm{CH}_{2} \mathrm{O}_{-}\right)$, and $8.98 \mathrm{ppm}\left(9 \mathrm{H}\right.$, singlet, $t$ - $\left.\mathrm{BuCH}_{2}-\right)$.

Anal. Calcd for $\mathrm{C}_{14} \overline{\mathrm{H}_{26}} \mathrm{~N}_{2} \mathrm{O}: \mathrm{C}, 70.54 ; \mathrm{H}$, 10.99; N, 11.75. Found: C, 70.27; H, 11.25; N, 11.67. 2,4-Diethoxy-6,6-dimethylheptanenitrile $(10 \mathrm{~b}, 1: 2$ telomer) was obtained from the distillate boiling at $95-100^{\circ} \mathrm{C}(4 \mathrm{~mm})$ in a yield of $4 \%$. NMR $\left(\mathrm{CDCl}_{3}\right): \tau 5.70(1 \mathrm{H}$, triplet, $-\mathrm{CH}(\mathrm{CN})-\mathrm{O}-), 6.0-6.8$ (5H, complex multiplet, $-\mathrm{CH}_{2} \mathrm{CH}-\mathrm{OCH}_{2}-$ and $\left.-\mathrm{CH}(\mathrm{CN})-\mathrm{O}-\mathrm{CH}_{2}-\right), 7.8-$ $8.4\left(4 \mathrm{H}\right.$, complex multiplet, $t-\mathrm{BuCH}_{2}-$ and $\left.-\mathrm{CH}-\mathrm{CH}_{2}-\mathrm{CH}\right)$, and $8.4-9.0 \mathrm{ppm}(6 \mathrm{H}$, complex multiplet, $2 \mathrm{CH}_{3} \mathrm{CH}_{2} \mathrm{O}-$ ), $9.03(9 \mathrm{H}$, singlet, $t-\mathrm{Bu})$.

Anal. Calcd for $\mathrm{C}_{13} \mathrm{H}_{25} \mathrm{NO}_{2}: \mathrm{C}, 68.68 ; \mathrm{H}$, 11.08; N, 6.16. Found: C, 68.43; H, 11.27; N, 5.92 . 
Reaction of 4,5-Dihydropyran with t-Butyl Isocyanide

cis-2-Cyano-3-t-butyl-tetrahydropyran was obtaned from the reaction of 4,5-dihydropyran with $t$-butyl isocyanide in a yield of $4 \%$ (bp $\left.90-92^{\circ} \mathrm{C}(8 \mathrm{~mm})\right)$. NMR $\left(\mathrm{CDCl}_{3}\right): \tau 5.18(1 \mathrm{H}$, multiplet, $J=3.0 \mathrm{~Hz},-\mathrm{OCH}-\mathrm{CN}), 6.15(2 \mathrm{H}$, multiplet, $\left.-\mathrm{CH}_{2}-\mathrm{O}-\right), 8.0-8.8(5 \mathrm{H}$, multiplet, $t$ $\left.\mathrm{Bu}-\mathrm{CH}-\mathrm{CH}_{2}-\mathrm{CH}_{2}-\right)$, and $8.97 \mathrm{ppm}(9 \mathrm{H}$, singlet, $t$-Bu).

Anal. Calcd for $\mathrm{C}_{10} \mathrm{H}_{17} \mathrm{NO}$ : C, 71.81; H, 10.25; $\mathrm{N}, 8.38$. Found: C, 70.96; H, 10.18; N, 8.37.

Reaction of $\alpha$-Methylstyrene with -Butyl Isocyanide 2-Phenyl-2,4,4-trimethylvaleronitrie (20) was obtained at a yield of $2 \%$ in the reaction of $t$ butyl isocyanide with $\alpha$-methylstyrene according to the above procedure. IR (neat): $2230 \mathrm{~cm}^{-1}$
$\left(\nu_{\mathrm{C} \equiv \mathrm{N}}\right) \mathrm{NMR}\left(\mathrm{CDCl}_{3}\right): \tau 2.40-2.90(5 \mathrm{H}$, multiplet, phenyl), $8.00\left(2 \mathrm{H}\right.$, singlet, $\left.-\mathrm{CH}_{2}-\right), 8.25$ $\left(3 \mathrm{H}\right.$, singlet, $\left.\mathrm{CH}_{3}\right)$, and $9.14 \mathrm{ppm}(9 \mathrm{H}$, singlet, $t$-Bu).

Anal. Calcd for $\mathrm{C}_{14} \mathrm{H}_{19} \mathrm{~N}$ : C, 83.53; H, 9.51;

$\mathrm{N}, 6.96$. Found: C, 81.89; H, 9.47; N, 7.31.

\section{REFERENCES}

1. Y. Yamamoto, T. Takigawa, and N. Hagiwara, Nippon Kagaku Zasshi (J. Chem. Soc. Japan, Pure Chem. Sect.), 87, 1355 (1966).

2. T. Saegusa, N. Takaishi, and Y. Ito, J. Org. Chem., 34, 4040 (1969).

3. T. Saegusa, Y. Ito, and N. Yasuda, presented at the 22nd Annual Meeting of the Chemical Society of Japan, Tokyo, April, 1969.

4. I. Ugi and R. Meyer, Chem. Ber., 93, 239 (1960). 